\title{
COMPASSION: LEARNING AND DOING
}

\author{
A Study on the Implementation of the Compassion Project at a \\ State School in Germany
}

\begin{abstract}
The Compassion Project was developed at parochial schools in Germany in response to the observed loss of solidarity in our society. Through social practicums, students taking part in the project have opportunities to encounter people who are reliant on the help of others in kindergartens, hospitals, workshops for the disabled, nursing homes and so on. In these encounters, pro-social attitudes such as helpfulness, communication, cooperation and solidarity are encouraged.

Within the theoretical framework explicitly set out and discussed in the article, an action-research based study design was developed. Participatory observation was used as the method for gathering data, and grounded theory was used for data analysis, with the aim of providing answers to the following question: Can the Compassion Project that has been piloted above all for high school (Gymnasium) students at Roman Catholic schools in Germany, and in particular the practical portion consisting of a social practicum, be implemented under empirically controlled conditions at a state middle school? If so, what adaptations need to be made to adapt the project to this population, and how can the insights gained from this research be applied to further developing the project?

The article presents a selection of results from the study, along with evaluation and perspectives for further study and reflection.
\end{abstract}

\section{Introduction}

Many authors and observers of religion and society have analyzed and at times bemoaned the effects of individualization, pluralization and detraditionalization processes. Because I do not want to merely complain about these tendencies and because I see the "Compassion Project" that was designed for church-affiliated schools as a positive new approach, I developed a pilot project for the implementation of the Compassion Project at a public school. The theoretical standpoint which I set forth (1) leads to consequences for the research question (2), quality criteria (3) and justification of the empirical methodology (4). Bearing in mind the initial situation (5), the concrete method is outlined (6) and selected results are presented (7). An evaluation and further perspectives (8) round out the article. 


\section{Theoretical Position}

In the recent past there has been a considerable amount of reflection on two things. First, the question has been asked whether practical theology has not in many cases simply taken over empirical methods from the social sciences without bringing to bear the potential for insight and action of our own faith (cf. Fuchs 2001). Second, it has been pointed out that the normativity inherent in empirical research in the field of practical theology needs to be explicitly disclosed (cf. Ziebertz 2002). For these reasons I begin by explicitating my theoretical position, from which flow further consequences in terms of research design and approach.

My understanding of the pedagogy of religion is rooted in a practical theology that "sees itself as a communicative action science" (Fürst 2002, 135) relying fundamentally on the "symbolic-critical method" (164). ${ }^{1}$ Key to this conception is the quest for a concrete "real symbolism of the hope for the Kingdom of God" (Fürst 2000, 28). Understanding is thus guided by an interest in perceptual patterns and forms of action ("Handlungsgestalten und Handlungsformen") in the context of "social and ecclesial signatures of the times" (ibid). The concept of pattern establishes a link with aesthetics: "Reflex reconstruction of Christian wisdom (sapentia) and of Christian taste (sapor, sapere Dei) or sense of community (sensus fidelium), as an intersubjectively constituted, communicatively (and interdisciplinarily) transmitted competence of aesthetic judgment and creativity, an instance of collective existential choice under the conditions of radical subjectivity and plurality" (29). Thus the focus is not only on perception (Wahrnehmung) and creation (Gestaltung) but also on judgment (Beurteilung). Hence I begin with the "perception of the historical circumstances of the personal/social (Christian) life and the (eschatological) promise contained therein" (30). Reciprocal critical analysis can encourage transformative processes towards "situationally characterized forms of communional life" through, among other things, the "development of innovative action models in diacony and caritas" (29).

A general line of connection from the "symbolic-critical method" to empiricaltheological research is seen in the "demanding and productive interplay of criticism and generativity" (Feser-Lichterfeld et al. 2002, 314). More specific conclusions that apply to our research context, i.e. the school setting, can also be drawn. We note that a researcher approaching his subject from the theoretical position described in the foregoing cannot simply pop into the school from time to time, armed with hypotheses and concepts that he has come up with at his desk, and initiate "transformative processes". Instead, the relationship between the researcher and his respondents must be understood as communicative and interpretive praxis, which means that in the field the object of the research is not 
only revealed but first of all constituted. This specific praxis leads to a chiefly qualitative approach in which the researcher must be in the field during the research process. The reason for this can be found in international action research as received by Altrichter and Posch (1990). ${ }^{2}$ The purpose of research in such a context must be to "support the development of (religious) pedagogical models and work on the realization of new ideas in cooperation with practicians" (Combe 2002,33). In the process, the specific laws of each of these areas must not be smoothed over: on the one hand, as Combe notes, the researcher is fulfilling a certain utilitarian purpose, while on the other hand there is a need to tie in the results and research questions with theoretical and thematic currents (33). While this approach might be considered risky in that more than a few traps await the unwary scientist navigating between these two aims, it also strikes me as rewarding, since if it is successful the possibility of making available "implementational knowledge" beckons (Combe 2002, 36), meaning that the researcher will be able to describe how certain tasks are handled under certain institutional and situational conditions. Against this background I turn now to the research question.

\section{Research Question}

In my view the "Compassion Project", a broadly conceived model of instruction and practical experience, is a promising means of providing students with an opportunity to acquire real-life experience that will serve as a basis for the religious education processes in today's complex and plural society (cf. Riegger 2003). Essentially the Compassion Project is about a synthesis between the practical experience that students acquire during their placements in social service institutions and classroom instruction in various subjects. In religious education class, for example, the class might take up the parable of the Good Samaritan in light of certain experiences that all of the students have had as part of their social practicums, in such a way that abductive correlation can occur (cf. Ziebertz et al. 2003). For this reason I believe that the project is an extremely valuable one and is worth implementing in state schools as well.

The Compassion Project was developed not only for private Catholic schools but has also been adapted for and implemented in German state high schools, especially as part of the 11 th grade curriculum (cf. Kuld \& Gönnheimer 2000, 119). I wondered whether and if so how this project could be adapted to public schools that end at the 9 th or 10th grade (in the German education system these are the Förderschule, Hauptschule and Realschule). I also wondered whether and how the project could be adapted from the privately-funded church schools (which are open to children of all faiths) to secular state schools. Because I assumed that transferring the model from church-affiliated high schools to state 
high schools would be easier than transferring it from a church-affiliated high school to a state middle school, I opted to go the latter route so that the more complex initial situation could be subjected to scientific scrutiny.

The quantitative study by Kuld and Gönnheimer offers some initial clues as to how this might be done. Their work, however, focused on the measurement of pro-social attitudes and how these changed as the result of the project, and did so exclusively from the students' point of view (cf. 2000, 27). As a result the kind of data suited to my implementation focus are limited at best. In their study, Kuld and Gönnheimer did not look at the effects of school type (cf. 2000, 25). They did, however, note certain differences specific to the Hauptschule: age difference, gender, family background, parental support, cognitive ability, moral judgment, integration into the social milieu and teacher commitment. As regards implementation, Kuld and Gönnheimer conclude that the Compassion Project can be adapted to the particular circumstances of the Hauptschule (cf. 2000,126 ). They note, however, that the nine classes they studied that were taking part in the project were Werkrealschulklassen ${ }^{b}$ (cf. 2000, 119) Students in these classes will be leaving school after the end of the 10th grade and do not have to take school-leaving exams in 9th grade. One of the project groups was also made up of students who had volunteered for the practicum, which would likely have facilitated the implementation of the Compassion Project, as would the fact that the school in question was a full-day school ${ }^{\mathrm{c}}$ in which the initial "Compassion" concept was introduced largely unchanged on the initiative of the principal (cf. 2000, 33).

From the foregoing it is evident that little relevant data is available about the Compassion Project at state schools in general and at state middle schools (Hauptschulen) in particular. Therefore an exploratory study would appear to be helpful. To narrow the focus, it was decided to limit the study to one state middle school, namely the Volksschule in Benediktbeuern, Bavaria. Additional

\footnotetext{
'Translator's note (B. Schultz): After primary school (Grundschule, grades 1-4), German students are streamed into one of several types of secondary schools: either the Gymnasium (grades 5-13) that leads to university-entrance qualification, the Förderschule for children with special educational needs, the Hauptschule (grades 5-9) for students who will be leaving school after the 9th grade to pursue a practical occupation and who attend vocational school one or two days a week, or the Realschule (grades 5-10) that ends with a state examination called Mittlere Reife (O-levels or secondary-I school-leaving certificate). In line with North American usage, the latter two-Hauptschule and Realschule - will generally be referred to as 'middle school', while Gymnasium will be translated as 'high school'.

'Special classes in the Hauptschule that go from grade 7-10 and in which students can also prepare to take the Mittlere Reife exam. - Tr.

'As opposed to the traditional German model in which the school day ends at lunchtime. - Tr.

dVolksschule is a combined Grundschule and Hauptschule, in other words a school that houses grades $1-9$ in one building. $-T r$.
} 
reasons for this choice will be given in the section on methodology. The question that was of interest from the point of view of religious pedagogy was the following:

Can the Compassion Project that has been piloted above all for high school (Gymnasium) students at Roman Catholic schools, in particular the practical portion consisting of a social practicum, be implemented under empirically controlled conditions at a state middle school (Hauptschule)? If so, what adaptations need to be made to adapt the project to this population, and how can the insights gained from this research be applied to further developing the project?

This question is best pursued in the context of school development processes, since it is here that changes can be examined. The many existing concepts for single-school development can be described in terms of a "three-way model" of school development (Rolff 1998, 304), made up of "organizational development", "instructional development" and "personal development". Within the system of the school, each of these pathways always leads to impacts on the others as well. When a project such as the Compassion Project is introduced at a school, teachers must re-examine and alter their professional routines; the organization of the school and that of the school year is affected; and in terms of instruction students are exposed to events and ideas that are not normally part of the school experience. In addition to these intra-scholastic systemic interactions there are also the extra-scholastic ones which include parents, 'consumers' (employers, universities), the press, the community, the school board and the ministry of education. In particular, greater involvement is likely to be asked of parents with the implementation of the Compassion Project.

Because of the many unanswered question regarding implementation research (cf. Rolff 1998, 308) and the complexity of a school's internal processes, the most suitable approach would likely be a qualitative-interpretive approach with a large exploratory element, which also takes into account the special conditions of school development at a state Hauptschule in Bavaria with regular classes preparing for school-leaving after the 9 th grade.

In connection with the research question stated above, I would like to reflect briefly on the development of the research question as part of the research process. My personal interest in the Compassion Project was wakened by a lecture by Lothar Kuld on July 7, 2001. That same day, in a conversation with another religion teacher, the question arose whether this project could also be implemented at a middle school. After some initial research in the literature I began to develop a number of ideas. Towards the end of the 2000-2001 school year, I presented my plan for a pilot study for the implementation of the 
Compassion Project at the Benediktbeuern Volksschule to interested colleagues at the school, an event that marked the beginning of the research project per se.

The main thrust of the question thus emerged in the preliminary phase of the research process. The focus on the practical portion (the social practicum) and the need for further development of the initial concept arose during the research process as a result of interactions in the field. In order to answer the research question in accordance with scientific standards, certain criteria must be fulfilled.

\section{Quality Criteria}

The criteria of objectivity, reliability and validity that are central for quantitative research are not readily applied to qualitative research. For this reason core criteria have been developed that can be adapted to different research projects (cf. Steinke 2000, 323-331). These specific social scientific core criteria need to be integrated with specifically religious-didactic reflection (cf. Porzelt 2000, 79).

For the present research project that looked at the possibilities of implementing the Compassion Project at a state middle school as a means of laying a foundation for correlative learning processes in religious education classes for all students, a number of criteria need to be considered. Intersubjective understanding depends on transparency of documentation. This is achieved by making the research question development process (see above), the data gathering and data analysis methods, and the documentation of the data open to all (see below). In the present article only an excerpt of the data can be documented, for obvious reasons. Coherence and relevance can be assessed only after the completion of the study, and are reflected in the results, evaluation and further perspectives presented at the end of this paper. The criterion of limitation involves determining and testing the generalizability of a theory that has been developed. The transferability of results obtained at a particular school initially poses a problem that cannot be resolved by comparative analysis of implementation studies at other schools since there are, to my knowledge, no comparable studies using this methodology. For this reason I have chosen to contrast results and data from different viewpoints (e.g. parents, teachers, etc.). In addition, some of Kuld and Gönnheimer's (2000) quantitative results also offer possibilities for contrast. Indication refers to the appropriateness of data collection and analysis methods. But since the indication of a research method is closely related to the core criterion of the empirical basis of theory development, both of these core criteria will be dealt with in the following section. Although the core criterion of reflected 
subjectivity essentially applies to the whole of the research process, specific problems and subjective assumptions are also reflected separately in the next section.

\section{Methodological Justification}

As noted at the beginning, the basic research design follows the action research concept. It is important, however, to make what Combe $(2002,33)$ calls "productive use of the differences in the logics of theory and praxis". A balance must be maintained between "analysis on the one hand and the school's expectation for participation and support on the other" (ibid).

As regards the research questions, the method was concretized as follows:

a. Begin directly with the concrete implementation project in the 9th grade at the Benediktbeuern state middle school.

b. Changes to praxis of Compassion Project implementation in the course of the study.

c. Exchange of views and information on a basis of equality between researcher and teachers/administrators, as well as dialogue with other stakeholders such as parents, students and social service institutions.

The further course of the project was characterized by alternating information gathering, discourse and practical actions. Field research on site, i.e. at the Benediktbeuern Volkschule, formed the starting point for all of these activities. The data gathering method consisted of participatory observation in the field, as well as examination of student outcomes relating to the social practicum. Since I - the researcher - am also a part-time teacher of religion at this school, I was a participant in the teaching/learning process as well as an observer. This situation would appear to meet Porzelt's $(2000,66)$ criterion of "naturalism" or greatest possible similarity to everyday conditions, for a research communication in the qualitative paradigm. To ensure that the inherent subjectivity of the observer does not affect the evaluation of the observations unnoticed, the researcher performs "self-observation" consisting of documentation of his own thoughts, emotions and projections (Friebertshäuser 1997, 525), as near as possible in time to the corresponding research observations. For observations to meet scientific criteria, potential sources of error as a result of perceptual distortion must be minimized through the appropriate training. ${ }^{3}$ At the beginning of the research process, the researcher attempts to describe in writing the complexity of the research-related observations that are likely to be made at the school. Selection of events is aided by a grid of thematic factors that serve to focus the observations. Because of the clear concentration of the observer gaze and the 
resulting selection of data from the many interactions with the participants, this focussed gaze extended from the beginning of the research project (July 2001) to the end of the research period (June 2002).

When using this kind of methodology it is important to consider what social roles the observer will be playing the field, because the presence of the observer and the roles he plays can alter the responses of the participants (cf. Friebertshauser, 521). Because I have also been part of the teaching staff at the school for several years, the dual role of teacher and researcher needed to be consciously assumed. To minimize the role conflict that was to be expected as a result of the collision of scientific with pedagogical intentions, the school year was organized in such a way that I would not teach the 9th grade classes that would be involved in the research project. Overall this dual role probably has the pragmatic advantage that the researcher is able to slip into a role that he normally plays in the field anyway. Thus no additional role needs to be learned, and the researcher is accepted as someone who has already spent many years in the field. Disadvantages could be that the researcher would have more difficulty maintaining a certain distance from the daily problem-solving role of the practician, technical difficulties in recording of observations, and not least the ethical problems associated with this kind of role (cf. Friebertshäuser).

The data analysis method used was Glaser and Strauss' Grounded Theory, which involves the "discovery of theory on the basis of data systematically collected in the course of social research" $(1998,12)$. A principle of grounded theory that is often followed in religious education in which it is considered possible to combine inductive and deductive methods as well as accompanying study of the literature (Strauss \& Corbin 1996) was applied. Using this method that I have already applied elsewhere (cf. Riegger 2002, 331ff.), medium-range object-based theories can be developed in the process of discovering new hypotheses. Since the data material is in the form of text in the broader sense (transcribed interviews, field notes, observation protocols, etc.), it can be considered suitable for analysis in our context. This applies both to the material obtained through participatory observation and to student outcomes produced in class that relate to the social practicum. The analysis itself consisted of multiple stages of coding, i.e. translating the data into defined concepts, which are classified into categories and finally condensed into a core category. From this core category, individual observations and results are then integrated into a theory, a form of conceptualisation. Essential to category development is that there must be a phenomenon to be explained (1) (for example fears or concerns relating to the social practicum) that is seen within a particular influencing context (2) (for example parental concern) and that causal conditions are identified (3) (e.g. the students would not be able to handle the demands of doing a practicum in a senior's home). Within the situation the individuals 
develop action strategies (4) (e.g. some parents object that there are not enough social service institutions within range of the school), which produce certain consequences (5) (e.g. the social practicum cannot be implemented) (cf. Strauss \& Corbin 1996, 75-93). Given its relatively frequent reception in pedagogy of religion, the adaptation of ground theory to analysis of the data for this project does not appear to require further justification.

\section{DIAGRAM 1: Process of constructing the research object}

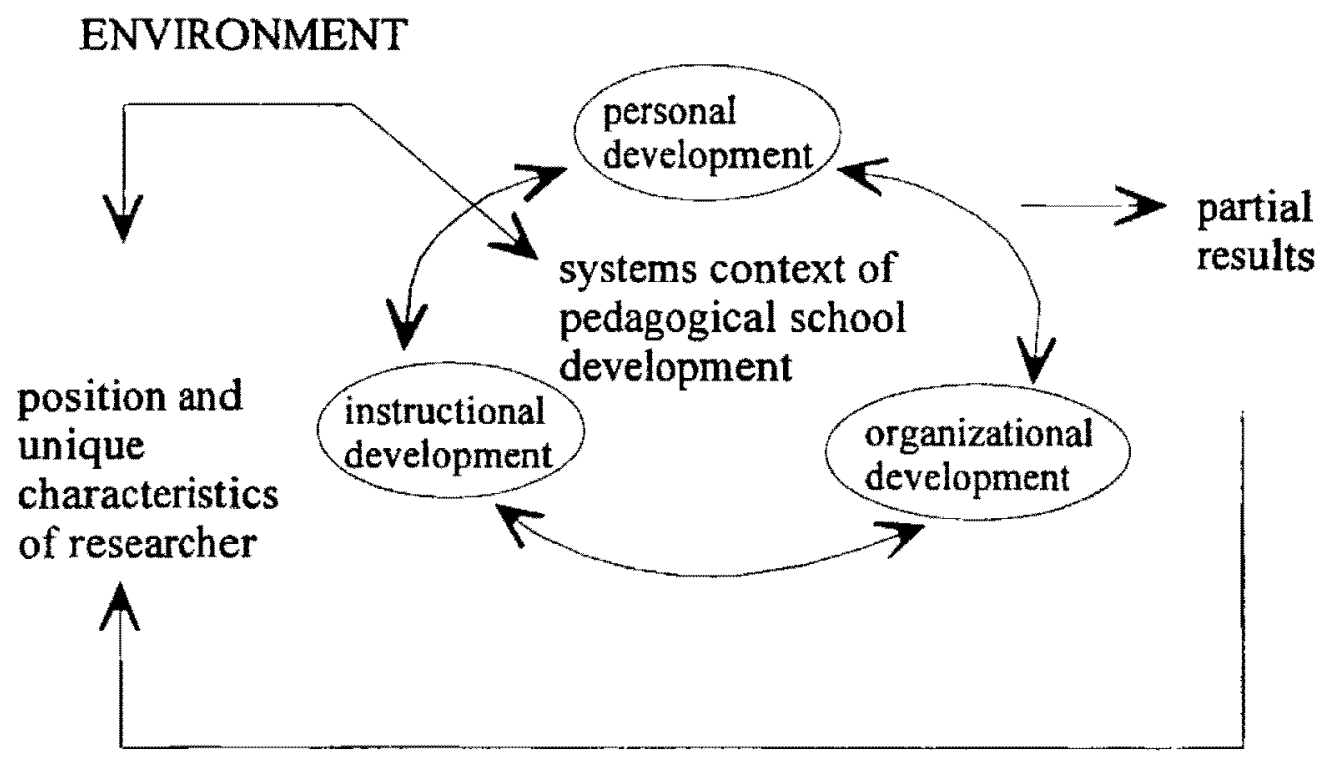

\section{Initial Situation}

The compassion concept that formed the basis of this project began as an initiative of the privately-supported Free Catholic Schools of Germany that was first described in 1994 (cf. Kuld 2001, 293). The idea is that all students in the 9th and 11th grades of the Gymnasium complete a two- or preferably threeweek practicum in a social service institution (such as a nursing home, hospital, orphanage or community health centre) of their choice. This practicum takes the place of regular classes for the two- or three-week period. Unlike vocational internships or co-op placements, the main purpose is not to acquire employment-related experience but rather to give students an opportunity to interact on a personal level with people who are reliant on the help of others in some way. The social practicum is not a new concept; these have long been in place at many schools and are done mainly to expose students to new experiences which are then used for pedagogical effect. Key aspects of the Compassion Project, 
however, are that the practicum experience is integrated into as many different school subjects as possible both before and after the practicum period per se; the school is closely involved in preparation and follow-up, and teachers visit the students at the placement site during the practicum. Students prepare for the practicum in class and then talk about and work through their experiences afterward, thereby forming new experiences. The school initiates the contact with the institutions where the students will be placed, and the latter issue certificates after the practicum describing the practicum situation and the student's role and contributions (cf. Hirsch 2000, 105f.)

"Compassion" is an "attitude of consideration for our fellow human beings and of 'co-suffering' that can not be prescribed by any law or policy and without which a society nevertheless cannot survive" (Kuld 2001, 294). The Compassion Project was developed as a way of addressing an empirically welldocumented social and moral deficit and the decline of solidarity in our society (cf. Kuld \& Gönnheimer 2000, 7). This tendency, which is part of the modern era, cannot be reversed by the school. The aim of the project, however, is to contribute to the "development of pro-social attitudes like helpfulness ... communication, cooperation and...solidarity with people who, for whatever reason, are dependent on the assistance of others" (Kuld 2001, 294). The core idea of the Compassion Project, which is substantiated by accompanying empirical study, is that "social practicums can lead to long-term changes in social behaviours and attitudes when they are integrated with classroom instruction that prepares for and follows up on the practicum experience with information, reflection and analysis" (Kuld, 393). From this we see that the crucial element is the embedding of the practicum in the didactical structure, in order that it is becomes a "value-oriented, interdisciplinary link between both the content and methodology of all subject fields" (Rekus 2000, 87). The moral and educational aim of the Compassion Project, as Rekus (75) describes it, is "to perceive the suffering and the needs of fellow human beings (knowledge and insight), to reflect on the significance of one's own charitable service to fellow human beings in terms of social obligation (ability to evaluate), and to assess one's personal abilities and limits in the service of others from the aspect of self-commitment, i.e. personal choice (dispositions for action)". Thus the intention of the project is not to produce feelings of pity. For even someone who feels no pity can come to the awareness that "helping others is necessary in certain situations according to humanitarian principles" (Rekus, 86). This kind of social obligation can be justified by reason (cf. Gönnheimer 2002, especially 190f.) and need not be guided by emotion alone. Because of this moral and educational purpose, there are good reasons to consider the project appropriate to be included as a compulsory part of the curriculum in state schools. 
As Kuld and Gönnheimer $(2000,10)$ point out, the Compassion Project can also be given religious meaning, though this is not essential. They believe that it is possible to include this dimension in church-affiliated schools, and refer to several sources, especially Johann Baptist Metz, as the theological basis for this view. According to Metz $(2000,13)$, compassion as the "key to the global program of Christianity in the age of globalization" holds universal relevance. ${ }^{4}$ In his view this kind of "pluralism-compatible universalism" (Metz, 12) can only be realized through a God discourse that draws its authority from its "remembrance of suffering" (11), namely remembrance of the meaning of the Hebrew zakar. In this sense, Metz $(1997,82 \mathrm{f}$.) says that history "is and remains ... remembered-narrated tradition - immanent of reason, that seeks to be practiced as liberating critique" and hence it is that one speaks of "dangerous memory". When confronted with a suffering world, suggests Metz $(2000,13)$, the first response is a "justice-seeking compassion" that yearns to stop the suffering.

Though we cannot go into detail here on the reception of Metz' theology by Kuld and Gönnheimer, it is worth noting that both believe that while the Compassion Project, which was initially conceived for church schools, can be transferred to state schools, the religious meaning cannot (cf. Kuld \& Gönnheimer 2000, 10). I would therefore like to mention, albeit briefly, other theological viewpoints which show that spontaneous actions apparently motivated by purely humanitarian compassion - absent any specifically religious interests or motives - correspond entirely to the will of the biblical God. Thus we find here a "convergence between theological and humanitarian motives ... a convergence of which the person performing the actions need not necessarily be aware". Compassion, then, is not "exclusively religious or even specifically Judeo-Christian action, but rather an elementary and universal human behaviour that transcends all cultural and religious boundaries" (Bopp 1998, 122). As a consequence of this theological understanding, compassion as a universal category is given a Christian underpinning, which can be justified internally in systems theory terms, even if from an external perspective (for example a non-Christian or non-religious view) this particular justification is incomprehensible. On the basis of this kind of justification of the concept as a whole, it is possible to incorporate Christian perspectives without negating others. In my view this lays the theological groundwork for the implementation of the Compassion Project at state schools, which are part of a pluralistic society.

From a Christian religious viewpoint we can summarize that compassion pathically experiencing the suffering of others - can mean God's compassion for humanity as well as human beings' compassionate care for their fellow humans. Thus compassion is a universal as well as a Christian principle. Theologically, compassion is also the remembrance of God's care of his people in the experience of the exodus, belief in the resurrection of Christ, and hope of 
salvation. By reminding us of God's compassion, compassion also constitutes the only appropriate response of human beings to the suffering of other human beings. ${ }^{5}$ It is allowing oneself to be touched by the suffering of others, of taking part in their suffering. Carried by hope, compassion implies both giving direct aid to people in need of help, and revealing and denouncing the structural causes of discrimination and suffering in society and the world. Not least it implies solidarity with those whose suffering cannot be alleviated. In all cases, though, praxis is the basis of a reflective approach.

The concept that has been briefly presented here was to be implemented at the state Volksschule Benediktbeuern. The school was not familiar with the Compassion Project up to that point. Benediktbeuern is in the German state of Bavaria, approximately 60 kilometres south of Munich. At the time of the project the total enrollment of the school was around 540, divided among the primary (Grundschule) and secondary (Hauptschule) grades. The primary school (grades 1 to 4) has three streams and the middle school (grades 5 to 9) two streams. In addition to the regular classes, there are also so-called "M classes" in the 7th and 8th grades. These are classes preparing for schoolleaving after the 10th grade (Mittlere Reife) rather than after the 9th grade (Hauptschulabschluss) as is the rule for other Hauptschule classes.

My access to the field was not a problem, since as a member of the teaching staff I was already in the field. The formal start of the project marked a certain break in the sense that $I$ assumed a dual role in relation to my colleagues. Although I had explained what this dual role would consist of, I did note on more than one or occasion during the study period that my colleagues treated me more as a fellow teacher than as a researcher. Overall I can say that my colleagues perceived me first and foremost as a person teaching religion at the school and second as someone carrying out research at the University of Augsburg. Because I did not teach the 9th grade classes and was thus able to distance myself from the teaching role, the participating students and especially their parents accepted me as a researcher. I was already familiar with this dual role from a previous project (cf. Riegger 2002, 317ff). All in all, I was successful enough in gaining access to the field and being accepted by all in my roles as researcher and teacher to lay the foundation for a lengthy and informative stay.

\section{Procedure}

\subsection{Time Line of Field Research}

After several exploratory talks with the class teachers, the school administration and several subject teachers that took place after July 7, 2001, a meeting was 
held on July 18 , which marked the official start of the project. The two class teachers of the future 9th grade classes, two subject teachers and I agreed to undertake the experiment of implementing the Compassion Project at this school. Requests concerning my teaching duties (i.e. that as a researcher I would not teach the two 9th grade classes) and timetable were communicated to the administration, which accommodated my needs in every respect. A meeting was set for September 7, at which further planning details would be ironed out.

The topic for the September 7 meeting, which was during the summer holidays, was the planning of the pilot project. Present at the meeting were the class teachers for the two 9th grade final-year classes, one subject teacher and myself. Questions regarding the nature of the Compassion Project were recapitulated and dates were set for informing parents about the project (at the parents' evening on September 20) and for the social practicum itself (the week of December 3 to 7). It was agreed that social practicum should be explicitly mentioned in the invitation to the parents' evening. I would give a presentation on the project at the parents' evening in my role as a researcher at the University of Augsburg, and would prepare an information sheet which could also be sent home to parents not attending that evening. Only after the parents had been informed would the students be told about the project in their classes. The selection of practicum placements and means of contacting the social service institutions would be decided once a positive response had been received, and this was subsequently done.

With regard to the execution of the practicum, I was able to visit some of the students in their various placements together with the class teachers, and through observation and conversations with the students and their placement supervisors was able to obtain a firsthand picture of the situation.

I was present at the first post-practicum class discussion (December 11) in both classes. The emphasis was on talking about the students' impressions and experiences of the practicum. I also accompanied the students when they spoke to newspaper reporters about their practicum experience (December 19) and when they spoke about the experience at a school assembly (January 31, 2002) at which parents, mayors, school board members and others were present. These interactions with the students conveyed additional insights. After the assembly on January 31 , interactions that were of significance for the study became highly sporadic. The project ended with a meeting on June 4 , in which retrospective impressions were shared one more time and a recommendation was prepared for the class teachers of the next year's 9th grade classes suggesting that they also take part in the Compassion Project, which they did. 


\subsection{Actual Data Base}

The detailed documentation of my observations was generally done after time spent in the field, generally by referring to field notes written on looseleaf paper. The advantage of paper over a research journal was that I always had plenty of sheets of paper on hand and was able to jot down key words and ideas as needed, whether in discussions with colleagues or in the classroom, without being too conspicuous. I found it useful to organize these sheets of notes in a binder, so as to be able to refer to them as needed. In making my notes, I transposed the local Bavarian dialect into High German to make it more widely intelligible. In addition to these data, I was given copies of 23 reports that students wrote about the social practicum. These student reports were produced as homework for German class and were typed on computer. The predominance of data relating to interactions with students and teachers is no doubt due to the frequency of these kinds of contacts in the field. This circumstance should not be confused, however, with the actual significance of the materials, since parents and guardians could certainly have refused to give permission for the students to take part in the project. The volume of data concerning the environment outside of the school was also not large. Observation was focused according to thematic categories, inasmuch as attitudes toward the social practicum became relevant, which was the case in a few situations. Permission to publish the data was not obtained for all data, but was obtained for those that appear in this paper. Names of people and places were altered to ensure anonymity, though in some of the cases described, persons with some knowledge of the circumstances would be able draw conclusions as to the identity of those involved. For ethical as well as practical reasons, not all of the available data were made available to the general public.

Of the 42 students in the two 9th grade classes during the project, one student was sick, having fallen ill a week before the practicum. A total of 41 students completed social practicums. One student who was supposed to do his placement at a seniors' home broke his arm two days before the start of the practicum, and as a result was transferred to a primary-grade classroom with his arm in a cast. The rest of the students were distributed as follows (boys/girls):

Kindergarten (11/9)

Workshop for people with disabilities (1/1)

Hospital or clinic $(8 / 2)$

Nursing home $(6 / 2)$

The distribution differed from the preferences originally expressed in that more students were ultimately placed in nursing homes than had asked for these placements. 


\subsection{Stages of Processing}

In accordance with grounded theory, the data were processed as follows:

The first stage was that of category development. The data were grouped according to themes, with the thematic groupings always justified by texts. Similar themes were grouped into larger categories, for example "genderspecific socialized role expectations". These are presented in more detail below.

In the second stage, the dimensions of the various categories were determined.

The third stage was that of interpretation. This involved formulating theories about the various results, as well as formulating a compassion concept for the project school.

\section{Results}

The results are not presented in the order that events unfolded but rather, for the sake of clarity, are organized into categories, starting with the core category and then looking at selected individual results.

\subsection{Core Category}

From the beginning of the research process, I saw the attitude toward the Compassion Project of all those involved as the central phenomenon to be explained. Though we began with the idea implementing the Compassion Project as developed by the Free Catholic Schools unchanged at our school in Benediktbeuern, two significant modifications soon arose. First, "attitudes towards the social practicum" soon emerged as the most important phenomenon to be explained, since not the Compassion Project but the social practicum was perceived by all participants as the main aspect. And secondly it became evident that minor adaptations of the initial concept would not be sufficient. What crystallized out was an implementation of the Compassion Project that, over the course of the research process, incorporated changes in response to the conditions encountered in practice.

\subsection{Derived Categories}

Observations, statements, practicum reports and so on, in other words the collected data, were first reviewed according to themes, without distinction as to whether they originated from teachers, parents, students or others. These themes 
are organized here into the three time phases 'before', 'during' and 'after' the social practicum.

\section{BEFORE THE PRACTICUM}

- vocational orientation

- practical application

- final exam

- fears, concerns

- $\quad$ gender-specific role expectations

- previous volunteer/social service

- pre-practicum instruction

- acceptance of the social practicum

\section{DURING THE PRACTICUM}

- placement institution

- $\quad$-activities

- $\quad$-practicum supervisor

- $\quad$-people the students will be helping

- $\quad$-feedback (approval)

- $\quad$ site visit by teacher

\section{AFTER THE PRACTICUM}

- $\quad$ experiences during the practicum (emotional responses, dealing with these emotions, fun)

- $\quad$-career plans, civilian service, "social service year"6

- $\quad$-reflections on life (gratitude)

- $\quad$-knowledge for life

- $\quad$ practicum-school relationship

In the following, not every category is examined in detail. Instead, one sample interaction is presented, along with the corresponding conceptualization.

\subsection{Sample Analysis}

During my first visit to one of the two classes to explain what the Compassion Project was all about, the female students expressed few or no reservations about the social practicum. Some of the statements made by male students were: 
(1) A: "We've never done anything like this before!"

(2) B: "What's a practicum supposed to be good for?"

(3) C: "Why should I work in a place like that?"

Analysis of these statements, which showed a combination of "male" + "(strong) negative response" and "female" + "no negative response" first of all lent credence to the hypothesis that there are differences between the sexes in the response to the social practicum. Therefore I arranged for another talk with the same class, during which this interaction (reproduced here in part) took place:

(4) Z (me): "The last time I was here I noticed that the boys in particular appear to have concerns about the social practicum."

(5) A: "Girls are just better at that kind of thing!"

(6) Z: "What we're going to do is have the girls continue with their math exercises, so that we men can talk amongst ourselves."

Students shifted around so that the girls could work on their math in one half of the classroom, while the boys talked with me in the other half.

(7) Z: "Now I'd be interested to know what it is that the girls can do better."

(8) A: "At home they look after little kids."

(9) D: "And they help with changing diapers."

(10) E: "They just know what to do with children."

(11) Z: "Is looking after children or going for walks with old people really so hard?"

(12) D: "What am I supposed to do if an old lady doesn't say anything when I go for a walk with her?"

(13) Z: "Who has some ideas about that?"

(14) F: "Our neighbour is 86 and sometimes he gets confused. When he sees $m e$, he always talks about the old days. I don't have to say anything. "...

During the further course of the conversation several boys shared their experiences having to do with young children, people with disabilities and especially old people. The girls appeared to be doing their work but were following the conversation very closely.

As regards attitudes toward the social practicum (phenomenon), the reference to the boys' concerns (4) can be seen as the starting point for a discussion (cause). During the presentation to the entire class (context), boy A states (action strategy) that girls have the skills needed for such a practicum (5), thereby summarizing the concerns expressed $(1,2,3)$ (consequences). Picking up on these concerns (cause), the setting for the discussion is changed (boys only). In 
this context several boys for the first time express more precisely (action strategy) what it is that they believe girls can do $(8,9,10)$. These skills are learned (10) and comprise looking after children (8) and helping with diapering (9). Nothing is said about skills the boys may have in this area. The resulting presumed consequence (apprehension about the social practicum) are expressed by $Z$ (11). At the same time the scope of the discussion is broadened to include old people (11), which is the start of further discussion in the boys' group. One boy asks (action strategy) about what do in the imagined situation of having nothing to talk about with an old lady (12), thereby concretizing insecurity. Another boy (F), who until then has not participated in the discussion, talks about his own experience with such concerns in a similar type of situation, noting that old people sometimes talk a great deal. This suggests the possibility to the other boy (consequence) that the situation he is apprehensive about can be handled. For space reasons we cannot go into the rest of the discussion; suffice to say that after this talk the boys in the class expressed markedly fewer concerns about the practicum.

To summarize, it can be noted that the initial supposition of gender-specific differences in attitude toward the social practicum (negative response) was not confirmed as such by the discussion in the boys' group. For on closer analysis it was found that negative expressions and attitudes about the practicum on the part of boys were determined less by biological than by social gender (acquired knowledge). In the new setting (boys only group), fears were expressed more specifically. As well, boys who did have knowledge of dealing with children, disabled people and old people joined in the discussion. A significantly higher tendency to respond negatively to the social practicum seemed to be associated with a markedly "masculine" gender identity. It was also found that constructive engagement with these gender-specific role expectations was indeed possible.

In the following a few other themes are presented briefly.

\subsection{Selected Results}

\subsubsection{Difference of Opinion between Teachers}

Kuld and Gönnheimer point out that teachers' acceptance of the Compassion Project can be traced essentially to teaching staff's inclusion in the decisionmaking process prior to implementation $(2000,68)$. What does this mean in practice? On September 7, 2001, the following interaction concerning student placement in nursing homes unfolded between two teachers, both of whom had agreed to the project at the meeting of July 18.

$\mathrm{X}$ (class teacher): "Looking after old people is too difficult for the students!"

Y: "Why should it be too difficult?"

$\mathrm{X}$ : "I visit a nursing home fairly frequently. One of my relatives is there. Sometimes he doesn't remember where he is. After an hour or an hour and 
a half visiting him, I'm always glad to get out of there. A nursing home just isn 't a suitable placement for the students."

$\mathrm{Y}$ (voice rising): "Now just a minute! You are confusing your own experience with what the students will be doing. It could be entirely different for them."

$\mathrm{X}$ : "But nursing homes are so depressing!"

$\mathrm{Y}$ : "It may be depressing for you when you go there."

$\mathrm{X}$ : "It would be expecting too much of the students."

$\mathrm{Y}$ : "Getting old is a fact of life. It won't do the students any harm to see that." (Silence.) Change of subject.

The other persons present at the meeting listened to this exchange without saying a word. What happened after that? The confrontation was never brought up again discursively. Not only did X support the Compassion Project, but four students completed their placement in a nursing home.

$\mathrm{X}$ 's action strategy could not be resolved. Was it insight by $\mathrm{X}$ that led her to drop her resistance to students doing their practicums in a nursing home? Surely human behavior is sometimes a product of contradictory motivations. What effects does this have on the implementation project?

\subsubsection{Students with Negative Attitudes toward the Practicum}

There were a few students who regularly expressed negative opinions about taking part in a practicum. Kuld and Gönnheimer concluded that the school must endeavor to open the minds of such students prior to the practicum by helping them to discover how the project can benefit them $(2000,101)$. An example of this can be seen in the following interaction:

G: "Why should I do a social practicum? I'll never have anything to do with any of that social work stuff."

$\mathrm{Z}$ (me): What field do you plan to work in?

$\mathrm{G}$ : "I'm going to be a bricklayer!"

$\mathrm{Z}$ : "I'm sure you've seen that our school building was not designed to be accessible to disabled people. That's why they had to put in a wheelchair ramp afterwards. If you have experienced what it is like to push someone in a wheelchair, then if you were working on a building like this you would be able to say how these ramps should be built."

G: "But I can't tell the master things like that during my first year as an apprentice."

Z: "I agree, but they also need journeymen who don't just wait to be told what to do, who think for themselves."

The student completed his practicum in a kindergarten. 


\subsubsection{Perspective of a Kindergarten Teacher}

During a visit by a student to a kindergarten, the teacher took me aside and asked:

S: 'I think it's a good thing that the students are doing a social practicum. But why? They never used to in the past."

Z: "Take that boy over there. He's an only child and lives with his mother. He practically never has anything to do with little children, as he almost certainly would have in the old days."

S: "I never thought of that."

The social practicum seems to offer students an opportunity for experiences that once would have been taken for granted, but today are often non-existent for many people.

\subsubsection{Authentic Encounters with Needy People}

Remarks such as the following suggest that the majority of students were stimulated to think about a wide range of social issues and to develop interpersonal and intrapersonal skills through their personal encounters and experiences with people who depended on their help.

$\mathrm{H}$ : "The week of the social practicum was very special for me, because now I can imagine how people with disabilities live, work and do sports." (Female student in a disabled workshop, age 15)

I: "I believe that everyone should spend some time working in a place like this." (Male student in a nursing home, age 14)

$\mathrm{J}$ : "I didn't expect that working in a hospital would be so easy." (Female student in a hospital, age 14)

$\mathrm{K}$ : "I became very fond of some of the children at the daycare centre and they didn't want me to leave. That was the best thing about my social practicum." (Student in a daycare centre, age 15)

\subsubsection{Vocational Orientation}

As Kuld and Gönnheimer have pointed out, the effect of the practicum on career choice (cf. 2000,125 ) was relatively limited with only $10 \%$ of students reporting such an effect ("...I now know that I want to be a nurse"). (How the practicum affected students' plans for civilian alternative service or a "social service year" could not be assessed here.) The four students quoted above did say, however, that without the backing of the school as part of the Compassion Project, they probably would not have dared to do a practicum in a social service institution (with the exception of a kindergarten). Thus this aspect must be considered not just in terms of the numbers, but also in terms of quality of effects. 


\subsection{Conceptualization of the Compassion Project}

The results summarized above are relatively closely tied to the corresponding data. A higher degree of abstraction is attained when these results are structurally captured in a conceptualization. The direct empirical validity is limited to the 9th grade classes in the state school where the study took place. Beyond that, however, I view this conceptualization as an objective starting point, in the action theory sense, for a possible implementation of the Compassion Project at state schools, though of course it will have to be corrected or modified by further empirical data in order to be considered proven. I would expect the fewest modifications for state schools in which the institutional conditions are very similar to those of the school in the study (e.g. practicums included in the curriculum), in other words middle schools (Hauptschule) with regular classes to 9th grade; special education schools (Förderschule); middle schools (Hauptschule) with classes preparing for school-leaving after 10th grade, as well as middle schools (Realschule) that end at the 10th grade. I also see possibilities for transferring the model to state high schools (Gymnasium).

The Compassion Project concept presented below applies to the school as a whole, i.e. at a level where subject-specific factors are taken into account to only a very limited degree, if at all.

\subsubsection{Aims}

The primary aim of this project is to encourage students to concern themselves with social issues in a realistic learning situation (Gönnheimer 2002, 198). The project seeks to encourage and develop "pro-social attitudes like helpfulness ... communication, cooperation and ...solidarity with people who are reliant on the help of others for any reason" (Kuld 2001, 293). The focus is on facilitating interpersonal encounters, promoting authentic experience of human existence and interpersonal reality, and providing an opportunity to develop greater sensitivity to the suffering, the needs and the happiness of others. The project does not aim to produce feelings of pity or to directly effect certain types of behavior.

The secondary aim is to assist students in choosing a vocational orientation, or to give them options for where they might complete their civilian alternative service or a "social service year" if that is what they choose to do. This aspect merits special emphasis, since the intensive focus on issues related to the social practicum throughout the school year is an opportunity for the school to provide support and guidance in this area. 


\subsubsection{Basic Requirements}

To realize the project aims, the following guidelines have been identified as basic project requirements:

1. The practicum in social service institutions is implemented within the administrative framework of the vocational practicum that is already part of the school curriculum. In this way the project is given a legal-administrative basis. If students will also be doing a vocational practicum prior to the social practicum in the same school year, it makes sense to select the placements in such a way that occupations in the social-service area are tried out during the vocational practicum. This allows for more intensive guidance.

2. Every student in a given class or grade completes a social practicum. The students choose a placement in consultation with the staff responsible for this and attend a placement interview. This allows them to familiarize themselves with the institution beforehand, resolve any fears or concerns, and prepare for the practicum, thereby reducing the time needed to adjust once the actual practicum begins. Practicum placements can be in kindergartens, orphanages, daycare centers, special education schools, hospitals, community health centers, workshops for people with disabilities, residences for new immigrants or refugee claimants, nursing homes, etc. For one week the students perform some kind of 'caregiving' work, during which time they undergo a variety of personal experiences. These may be happy or sad, attract the students or repel them, provoke pity or toughen them up.

3. The practicum is especially important for promoting class spirit, because in the classroom community all of the students are able to talk about their experiences. The students learn about their classmates' experiences, and share with one another their difficulties, their feelings of sadness or relief, and new skills and knowledge they have acquired.

4. Didactic guidance and support are central to this project. Students prepare for the practicum in as many different subjects as possible, in interdisciplinary and multidisciplinary assignments. After the practicum they follow up on the experience and finally evaluate it. Much of this preparation and follow-up will take place in religion or ethics class. Individual guidance of the students (choice of an appropriate placement) is particularly important, for instance through oneon-one talks with the teacher.

5. The teacher visits his or her students at the placement site and observes firsthand the types of work they are doing and their behavior. The observations and personal experiences of students and teachers can be taken up in various classes. Even topics on the regular lesson plan can become intensely interesting when examined in light of the students' personal experiences. 
6. Each participant receives a certificate from the institution where the practicum was completed, describing the nature of the placement and the work performed. A positive mention is also included in the student's school report.

7. The school coordinates and controls the selection of practicum placements as well as the students' contact with the institutions (placement interviews) and provides support and guidance during the practicum. Having a staff member serve as placement coordinator is very helpful.

In the final section, the findings are evaluated and implications for the further development of the Compassion Project are discussed.

\section{Evaluation and Implications}

\subsection{Implementation of the Compassion Project}

From the sample results that have been presented here, albeit in abbreviated form, it seems clear that given close and reciprocal communication on a basis of equality between all of the subjects (researcher, teachers, students, parents and others), people's views and attitudes can change. When the researcher's observes, documents and analyzes events and experiences from the point of view of a participant in the interactions of school praxis, as opposed to reconstructing them from the distance of non-participatory research, it seems that cognitive feedback can take place relatively close in time to the experiential situation and appropriate consequences can be drawn and acted on. The selected results presented above are typical, key events that could help to enhance sensitivity in future implementation projects and serve as a possible point of departure for conceptualization.

\subsection{Social Practicum and Religious Education}

To start with it is important to recall the focus of the study, which was to examine the conditions under which the potential for initiating learning processes in religion education classes exists. In religious education classes that draw on the social practicum, it is the didactic significance of the correlations that needs to be emphasized over the practical learning aspects. For the experiences that the different students have had during their social practicums can serve as a platform in religious education class for grappling seriously with the realities of the plural society. The religion teacher could then propose 'daring hypotheses' in order to make connections between aspects of the social practicum one the one hand and Christian religious experiences from past and present on the other (cf. Ziebertz, Heil \& Prokopf 2003, 27f.) In this way, the 
successful implementation of the social practicum can at least help to enlighten the great "unknowingness" (22) of religion teachers when it comes to opening up lines of communication with young people.

From the perspective of hermeneutics, the practice of compassion can be turned into a "practical hermeneutics" in religious education class. For, as Fuchs (1994, 137) says, "he who acts in solidarity with those who suffer has the praxis that teaches us and allows us to speak meaningfully of and with God. It is only through this praxis that the biblical stories are grasped in a way that can be of service to others and transmitted in a practical way". Anyone who has experienced, in direct encounters with needy people, what the so-called needy have to tell those who give help, perhaps also has a better understanding of what it meant when Jesus asked a child to come to him, not to give the child help, but to make it clear that "we can learn from the child himself how to accept the Kingdom of God" (ibid). Another aspect is the "Christian act as an experienceable truth criterion" (ibid) for Christian faith (orthopraxis). The social practicum provides a practical, experientially-based structure which is shared by all of the students.

Theologically, the project provides a means for examining, on the basis of direct experience, the inner connections between the compassion that God shows us and that which He demands of us, between giving and giving up, comfort and claim, grace and morality. For on the one hand the social practicum provides an opportunity to realize, through the experience of mutual compassion, what God's love for humanity means, and on the other hand not to 'ethicize' God, i.e. to view Him solely in terms of behavioral prescriptions (cf. Fuchs, 131f.) And as religion teachers we must bear in mind that the theme of compassion as the search for justice, of tracking down the causes of suffering and raising awareness of them in social contexts (cf. Fuchs, 134f.) can also be dealt with in the classroom.

Once a foundation has been laid, this theme can be more strongly emphasized.

\subsection{Religious Pedagogy as Science}

With the research design presented here, I have attempted to empirically implement the described theoretical position by transcending the classic subject-object dichotomy with the help of the researcher position as a 'third party', without trying to smooth over the differences in the logic of either side. In such a conception, the primary task of the researcher could be to identify correlations between theory and praxis, more specifically between theories developed by the theoreticians (i.e. academics specializing in the pedagogy of religion), theories of the practicians (i.e. religious education teachers), and the 
actual, effective praxis, and to make these correlations more productive (cf. Riegger 2001, especially $264 \mathrm{ff}$.) In this concept, the researcher does not seek to maintain the particularities of the different logical systems primarily by maintaining a substantive and formal distance to the other field. Rather, the position of the researcher as the 'third party' introduces a higher level of reflection, which allows for both distance and interconnection and thus expands the perceptual scope. In terms of methodology this requires the researcher's skills to be expanded beyond purely content-based ones (for example exposing one's own attachment to supervisions). In terms of structure, the researcher might succeed in finding analogies among the logics of the different fields, such that transformations processes that may occur between the fields can be included in the reflections. Correlations, discontinuities or even unexplained irritations between the different fields could be examined. Logically, perception and creativity including critical evaluation would be focused on the practical experience and not only in abstract form, but with consideration of situational conditions and local knowledge about successful or unsuccessful (communal) praxis. This would be an opportunity to present the truly effective processes in such a way that they can be grasped by outsiders. Theologically such a correlative determination in religious pedagogical research could be substantiated and validated with reference to Trinitarian theology and soteriology, either separately or together.

\section{Conclusion}

In closing I note that the pilot project reported on here was productive both as regards generating information that would contribute to successful implementation and as regards the actual implementation at the Volkschule Benediktbeuern. It is my hope that these results will serve as the basis for further implementations of the Compassion Project at state schools, as well as providing impetus for further research and reflection in both pedagogy and didactics of religion, and in practical theology.

\section{NOTES}

${ }^{1}$ See also Bopp 1998 as well as, with slightly different emphasis, Mette, Norbert (2002). Zwischen Handlungs- und Wahmehmungswissenschaft - zum handlungstheoretischen Ansatz der Praktischen Theologie [Between action theory and perception theory - The action theory approach in Practical Theology]. In: Pastoraltheologische Informationen 22, 28-31.

${ }^{2}$ Herbert Altrichter uses the terms "action research", "action theory" and "teacher research" synonymously (cf. Altrichter, H. (1990). Ist das noch Wissenschaft? Darstellung und wisenschaftstheoretische Diskussion einer von Lehrern betriebenen Aktionsforschung [Is this still science? Description and theoretical discussion of an action research study carried out by teachers]). Altrichter sees the formulation of the research program as the "framework" that remains open to 
additions and modifications. Overall, despite the discernible differences, he notes that the terms praxis theory, teacher research, action theory, action research, team theory and so on seem to "point in a similar direction" (Altrichter, H. (2002), Aktionsforschung als Strategie zur Förderung professionellen Lernens [Action theory as a strategy for promoting professional learning]. In: Breidenstein, G., Combe, A., Helsper, W. \& Stelmaszyk, B. (eds..), Forum Qualitative Schulforschung 2: Interpretative Unterrichts- und Schulbegleitforschung, (194-220). Opladen, 194). With regard to the different interpretations of action (Handlung), a certain agreement on the intentionality does appear to exist, which corresponds to some extent with our understanding of transformational processes (cf. Gerstenmaier, J. (2002). Philosophische Bildungsforschung: Handlungstheorien [Theory of philosophy of education: Action theories]: In: Tippelt, R. (ed.), Handbuch Bildungsforschung, (155-168). Opladen, 158).

${ }^{3}$ In a formal sense I can point to extensive preparation over a number of years through internships and supervisions as part of my social work training, as well as training in clinical pastoral care (CPE) and group therapy (ASIS). As regards content, I have concerned myself with this subject during my academic studies, and also acquired practical experience during a four-week stint as an orderly in a trauma ward and weekend 'encounter stays' in prisons, orphanages and institutions for people with disabilities.

${ }^{4}$ For a critical treatment see Haker, H. (2001. "Compassion" als Weltprogramm des Christentums? ["Compassion" as a world program for Christianity?]. In: Concilium 37, 436-450.

${ }^{5}$ In the more recent literature see also Bopp 1998, and Bopp (2002). Barmherzigkeit, Praktischtheologisch [Compassion in practical theology]. In: Baumgartner, K. \& Scheuchenpflug, P. (ed.), Lexikon der Pastoral, Bd. 1, (130-134). Freiburg i. B., as well as Dybowski, S. (1992), Barmherzigkeit im Neuen Testament - Ein Grundmotiv caritativen Handelns [Compassion in the New Testament - A basic motif of charitable action] Freiburg i. B.; Zehetbauer, M. (1999), Die Polarität der Botschaft Jesu. Konsequenzen für die Ethik [The polarizing message of Jesus. Consequences for ethics]. Regensburg.

${ }^{6}$ Civilian service (Zivildienst) is an altemative to compulsory military service. The "social service year" (soziales Jahr) is a year spent by a young person, usually after completion of high school, working as a volunteer in hospitals, social services, etc. $-T r$.

\section{LITERATURE}

Altrichter, H. \& Posch, P. (1990). Lehrer erforschen ihren Unterricht: Eine Einführung in die Methoden der Aktionsforschung [Teachers study their teaching: An introduction to the methods of action research]. 2nd revised edition. 1994. Bad Heilbrunn.

Bopp, K. (1998). Barmherzigkeit im pastoralen Handeln der Kirche. Eine symbolischkritische Handlungstheorie zur Neuorientierung kirchlicher Praxis [Compassion in the pastoral work of the Church: A symbolic-critical action theory for a new orientation of ecclesial praxis], Munich.

Combe, A. (2002). Interpretative Schulforschung - konzeptionelle Überlegungen [Interpretive school research - Conceptional considerations]. In: Breidenstein, G., Combe, A., Helsper, W. \& Stelmaszyk, B. (eds.). Forum Qualitative Schulforschung 2: Interpretative Unterrichts- und Schulbegleitforschung (29-37). Opladen.

Fester-Lichterfeld, U. \& Kläden, T. (2002). Empirisch-theologische Forschung Stolperstein oder Baustein der Pastoralästhetik? [Empirical-theological research: stumbling block or building block for pastoral aesthetics?] In: Fürst, W. (ed.). Pastoralästhetik. Die Kunst der Wahrnehmung und Gestaltung in Glaube und Kirche (311-319). Freiburg i.B. 
Friebertshäuser, B. (1997). Feldforschung und teilnehmende Beobachtung [Field research and participatory observation]. In: Friebertshäuser, B. \& Prengel, A. (ed.). Handbuch Qualitative Forschungsmethoden in der Erziehungswissenschaft (503534). Weinheim.

Fuchs, O. (1994). Diakonia: Option für die Armen [Diakonia: Option for the Poor]. In: Konferenz der bayerischen Pastoraltheologen (ed.). Das Handeln der Kirche in der Welt von heute. Ein pastoraltheologischer Grundriß (114-144). Munich.

Fuchs, O. (2001). Relationship between Practical Theology and Empirical Research. In: Journal of Empirical Theology 14/2, 5-19.

Fürst, W. (2000). Symbolisch-kritischer Ansatz der Praktischen Theologie als Wissenschaft - Bausteine einer künftigen Pastoralästhetik [The symbolic-critical approach of practical theology as a science - Building blocks of a future pastoral aesthetics]. In: Pastoraltheologische Informationen 20, 28-31.

Fürst, W. (2002). Mit den Augen des Glaubens. Präliminarien und Strukturelemente einer theologisch verantworteten Ästhetik des pastoralen Handelns [With the eyes of faith: Preliminaries and structural elements of a theologically sound aesthetics of pastoral action]. In: Fürst, W. (ed.). Pastoralästhetik. Die Kunst der Wahrnehmung und Gestaltung in Glaube und Kirche (131-165). Freiburg i.B.

Glaser, B. \& Strauss, A. (1998). Grounded Theory. Strategien qualitativer Forschung. Bern. Published in English as: Glaser, B. \& Strauss, A. (1967). The Discovery of Grounded Theory - Strategies for Qualitative Research. New York.

Gönnheimer, S. (2002). Schule und Verantwortung: Zur Bedeutung einer ethischen Kategorie in Erziehung und Unterricht [School and Responsibility: On the importance of ethics in education and schooling]. Frankfurt a.M.

Hirsch, F. (2000). Umsetzungsmöglichkeiten an Schulen [Implementation opportunities in schools]. In: Metz, J. B., Kuld, L. \& Weisbrod, A. (eds.). Compassion. Weltprogramm des Christentums. Soziale Verantwortung lernen (101-108), Freiburg i.B.

Kuld, L. (2001). Compassion. In: Mette, N. \& Rickers, F. (ed.). Lexikon der Religionspädagogik, Bd. 1 (293-295). Neukirchen-Vluyn.

Kuld, L. \& Gönnheimer, S. (2000). Compassion. Sozialverpflichtetes Lernen und Handeln [Compassion. Pro-social learning and doing]. Stuttgart.

Metz, J.B. (1997). Zum Begriff der neuen Politischen Theologie [On the concept of the new political theology] 1967-1997, Mainz.

Metz, J.B. (2000), Compassion. Zu einem Weltprogramm des Christentums im Zeitalter des Pluralismus der Religionen und Kulturen [Compassion. Towards a world program for Christianity in the age of pluralism of religions and cultures]. In: Metz, J.B., Kuld, L. \& Weisbrod, A. (eds.). Weltprogramm des Christentums. Soziale Verantwortung lernen (9-18). Freiburg i.B., First published in: Süddeutsche Zeitung 24/25/ 26.12.1997, Nr. 296

Porzelt, B. (2000). Qualitativ-empirische Methoden in der Religionspädagogik. Grundlagen - Zugänge - Aktuelle Projekte [Qualitative empirical methods in religious pedagogy. Principles, applications, current projects]. In: Porzelt, B. \& Güth, R. (eds.), Empirische Religionspädagogik (63-81). Münster.

Rekus, J. (2000). Compassion - ein erlebnisbezogenes Bildungskonzept [Compassion: an experience-based educational concept]. In: Metz, J. B., Kuld, L. \& Weisbrod, A. (eds.). Compassion. Weltprogramm des Christentums. Soziale Verantwortung lernen (75-88). Freiburg i. B. 
Riegger, M. (2001). Lemen Religionslehrerinnen und -lehrer das Falsche? Zur Entwicklung von Lehrerkompetenzen am Lernort Hochschule [Are religion teachers learning the wrong things? The development of teacher competencies in high schools]. In: Mendl, H. \& Schiefer Ferrari, M. (eds.). Tradition - Korrelation Innovation. Trends der Religionsdidaktik in Vergangenheit und Gegenwart (250269). Donauwörth.

Riegger, M. (2002). Erfahrung und Glaube ins Spiel bringen [The uses of faith and experience]. Stuttgart.

Riegger, M. (2003). Sozialverpflichtetes Lernen und Handeln: Das Compassion-Projekt an staatlichen Schulen als kritisch-konstruktiver Beitrag zur Bildung verantwortlicher Heranwachsender [Pro-social learning and doing: The Compassion Project at state schools as a critical-constructive contribution to the education of responsible young people]. In: Arntz, K., Hafner, J. \& Hausmanninger, Th. (eds.). Mittendrin statt nur dabei: Christentum in pluraler Gesellschaft, (in printing). Regensburg.

Rolff, H.-G. (1998). Entwicklung von Einzelschulen: Viel Praxis, wenig Theorie und kaum Forschung - Ein Versuch, Schulentwicklung zu systematisieren [Development of individual schools: much practice, little theory and almost no research - An attempt to systematize school development]. In: Rolff, H.-G., Bauer, K.-O., Klemm, K. \& Pfeiffer, H. (eds.). Jahrbuch der Schulentwicklung, Bd. 10 (295-326). Weinheim.

Steinke, I. (2000). Gütekriterien qualitativer Forschung [Quality criteria for qualitative research]. In: Flick, U., Kardorff, E. \& Steinke, I. (eds.). Qualitative Forschung: Ein Handbuch (319-331). Reinbek bei Hamburg.

Strauss, A. \& Corbin, J. (1996). Grounded Theory: Grundlagen Qualitativer Sozialforschung. Weinheim. Published in English as: Strauss, A. \& Corbin, J. (1990). Basics of Qualitative Research. Grounded Theory Procedures and Techniques. San Francisco.

Ziebertz, H.-G. (2002). Normativity and Empirical Research in Practical Theology. In: Journal of Empirical Theology 15/1, 5-18.

Ziebertz, H.-G. , Heil, S. \& Prokopf, A. (2003). Gewagte Hypothesen - Abduktion in der Religionspädagogik [Daring hypotheses - Abduction in religious education]. In: Ziebertz, H.-G., Heil, S. \& Prokopf, A. (eds.). Abduktive Korrelation (11-31). Münster.

Manfred Riegger, is academic advisor to the Chair for Catholic Religious Didactics at the University of Augsburg and teaches religious education at the Volkschule Benediktbeuern. His address is: Dr. Manfred Riegger, University of Augsburg, Faculty of Theology, Universitätsstr. 10, D-86159 Augsburg, e-mail: Manfred.Riegger@KTHF.Uni-Augsburg.de 